\title{
HOW MANAGEMENT TOOLS HOLISTICALLY SUPPORT ENTERPRISES' OPERATION IN SUPPLY CHAINS?
}

\author{
Sonja Treven* \\ Duško Uršič $\check{L}^{* *}$ \\ Walled Rashad ${ }^{* * *}$
}

Received: 18. 3. 2019

Original scientific paper

Accepted: 5. 6. 2019

UDC 658.7

DOI https://doi.org/10.30924/mjcmi.24.1.1

\begin{abstract}
The paper examines how utilization of management tools supports enterprises' operating in supply chains. The paper critically reviews the results of a previous, survey-based study, with a sample of 198 employees from Slovenian organizations, who assessed utilization of management tools in their organizations. With hierarchical regression analysis authors test the associations between management tools' usage and enterprises operating in supply chain; the impact was controlled with the most significant personal and organizational drivers of management-tools usage. Results show that loyalty management, core competences, and scenario and contingency planning are most strongly associated with the supply chain management's activities in organizations. The traditional supply chain management' tools, like outsourcing, lean production and total quality management, are
\end{abstract}

\section{INTRODUCTION}

Author examined how the applied management tools (MTs) supported enterprises operating in supply chains. A significant currently not considered to be important vehicles for supporting enterprises' participation in supply chains. The results from this study suggest rethinking of the current focus of management tools utilization, when organizations try to improve their participation in supply chains. More management tools were measured than in earlier studies regarding management tools, supporting enterprises' participation in supply chain; relations between management-tools utilization and enterprise participation in supply chain were empirically examined. In addition, the most commonly used management tools were considered simultaneously, which had not been done in prior studies.

Keywords: management tools, organization, supply chain management, systems approach, enterprise participation in supply chain.

body of studies investigates enterprises responses to needs and demands of their important environments (Porter, 1996; Kaplan and Norton, 2008; Mullins, 2016).

\footnotetext{
${ }^{*}$ Sonja Treven, PhD, Faculty of Economic and Business, University of Maribor, Maribor, Slovenia, E-mail: sonja. treven@um.si

${ }^{* *}$ Duško Uršič, PhD, Faculty of Economic and Business, University of Maribor, Maribor, Slovenia, E-mail: dusko. ursic@um.si

${ }^{* * * *}$ Walled Rashad, Reda Chemicals, Khobar, Kingdom of Saudi Arabia
} 
Researchers focused their attention on issues related to development (Armstrong, 2006; Fernandes et al., 2017), utilization (Van Assen et al., 2009; Fayezi et al., 2017), operating (Rothaermel, 2016; Carter et al., 2017), and management (Cooper et al., 1997; Dubey et al., 2017) of enterprises' cooperation in supply chains (SCs). Prior management studies broadened our understanding of specific contextual (Naylor et al., 1999; Raisinghani et al., 2005), and methodological factors (Lambert et al., 1997; Choudhary et al., 2013) for enterprises' cooperation in business environment.

As suggested some academics, like Kannan and Tan (2005), and Christopher and Holweg (2017), more attention should be paid to broader understanding of associations between business characteristics and participation of enterprises in SCs. Despite the theoretical foundations, which link the business orientation - i.e., defined by policy and strategies, and business operating e.g., defined by adequate activities, surprisingly little research has investigated specific management solutions' impact on the enterprises' participation in SCs (Dabic et al., 2013; Lambert and Enz, 2017). In practice, enterprises applied specific series of MTs; this is based on the notion that enterprises' goals and particularities define their selection of diverse solutions for their operating (Armstrong, 2006; Carter et al., 2017). Management studies revealed mechanism by which business orientation leads selection of management solutions in accordance with presumptions of their unity and harmonization (Christopher, 2000; Choudhary et al., 2013; Fernandes et al., 2017).

Less investigated are relations between different streams of management solutions and specific goals of enterprises, operating in SCs (Bhosale and Kant, 2016; Schneider et al., 2017). Several academics developed theoretical arguments that enable consideration of these connections through a (requisitely) holistic understanding of business reality by several systems theories (Von Bertalanffy, 1968; Francois, 2004; Mulej, 2007). As Dubey et al. (2017) and Schneider et al. (2017) find out, systems consideration can importantly improve management of enterprises' operating in SCs.

The present study followed previous studies with development and testing a new model that links the most used MTs and enterprises operating in SCs. Our model draws upon management theory regarding the MTs (Certo and Certo, 2011; Mullins, 2016), and SC-related theory regarding the enterprise operating in SCs (Myerson, 2012; Chopra and Meindl, 2015).

Following Whetten et al. (2009), and Podsakoff et al., (2012) recommendations about consideration of theories from different disciplines, we modified the selected theories to fit the specific objectives of the present contribution and used them for analysis of answers from 198 employees in Slovenian enterprises.

In order to address study of above mentioned associations, authors consider the impact of the most commonly used management tools in organizations on enterprises' participation in SC. This has been the missing link in the research about correlations between diverse streams of possible management solutions and possible specific orientations of enterprises. In our study, more management tools were measured than in earlier studies regarding management tools supporting enterprises' participation in supply chains. Moreover, the relations between MT utilization and enterprises participation in supply chain were examined empirically, where the most commonly used tools were considered simultaneously. This had not been done in prior studies. 
The methodological contribution of this study is the expansion of multi-disciplinary examination of MTs - i.e., as considered appearance forms of management solutions, and multi-level examination of correlations between MTs on operational level and enterprises operating in SCs on a macro business level. Practical implications outline complementary actions for future selection of MTs for improvement of enterprises' participation in SCs.

\section{THEORETICAL BACKGROUND}

\subsection{Supply chain}

In the current business environment a very promising solution for improvement of enterprises' results derives from the supply chain (SC) which "encompasses all activities associated with the flow and transformation of goods from the raw material stage, through all stages to the end user, as well as the associated information flow" (Blanchard, 2006, p. 26).

In our stay we followed Lambert et al. (1997; p. 1) which define SC as "the systematic, strategic coordination of the traditional business functions and the tactics across these business functions within a particular company and across businesses in the SC, for the purpose of improving the long-term performance of the individual companies and the SC as a whole". For other conceptualizations of SC see Slack et al. (2006), Wilson (2010), Bowesox et al., 2012, Arunagiri and Gnanavelbabu, 2014; Christopher, 2016).

The logistic and management researches exposed several kinds, types, and forms of SCs and relationships between the organizations included in SCs (Lambert et al., 1997; Blanchard, 2006; Christopher and
Holweg, 2017). Additionally, each enterprise can choose specific ways for its participations and operating in possible SCs from creation of its own $\mathrm{SC}-$ i.e., as focal member, to its inclusion in external SCs (Lambert et al., 1997; Rothaermel, 2016; Hugos, 2018). Studies also exposed importance of functional integrations for development of different SCs (Bowersox et al., 2012; Schneider et al., 2017). SCs functional integration enables achievement of the desired synergetic effects of their operating (Slack et al., 2006; Fayezi et al., 2017; Chopra, 2018). In addition, Lamber and Enz (2017), and Schneider et al. (2017) exposed importance of connections between functional integration and value chain for improvement of evaluations in judgments about contributions of each part for results of the whole SC.

Enterprises for their participation in SCs use various methodological, content- and circumstances-based solutions (Lambert et al., 1997; Slack et al., 2006; Chopra, 2018). For example, management studies reported about: (a) interest, goals, and approaches for enterprises inclusion in SCs (Prince and Kay, 2003; Christopher, 2016; Jaeger and Adair, 2016), and (b) ways of participation, courses, characteristics, and results of enterprises operation in SCs (Kannan and Tan, 2005; Bowersox et al., 2012; Fernandes et al., 2017).

More fragmented is the available knowledge about conceptualizations of SCs in diverse business environments (Rigby and Bilodeau, 2009; Psomas et al., 2014; Rigby and Bilodeau, 2015; Wang et al., 2015). Thus, several researches established importance of specific organizational, business, and institutional factors for enterprise's conceptualization of SCs (Zinnes et al., 2001; Dabic et al., 2013; Klafke et al., 2016). As the field of SCs has evolved, 
several academics - like Christopher and Holweg (2017) and Lambert and Enz (2017) - called for further studies on correlations between enterprises' specific management solutions and their operating in SCs.

\subsection{Management tools}

In the last thirty years academics and practitioners of management community developed over 200 new management ideas and corresponding solutions for improvement of enterprises' business and their cooperation with environment (Peet and Hartwick, 2009; Certo and Certo, 2011; Dubey et al., 2017).

These ideas have been applied in researches related to development, and operating of enterprises in the modern society (Kaplan and Norton, 2008; Rothaermel, 2016). Most important, they have been used as theoretical bridges for adaptation of enterprises' operating according to demands and expectations of society (Simchi-Levi et al., 2009; Potocan et al., 2016; Carter et al., 2017; Rothaermel, 2016).

Management literature remains highly fragmented in analysis of several management ideas in diverse content-, contextual, and methodological frameworks (Mullins, 2016; Christopher, 2016; Hugos, 2018). One reason for this fragmentation lies in difficulties among comparison of contentrelated different - sometimes even oppositional - management ideas, which result from specific philosophies, goals, and orientations of businesses (Prince and Kay, 2003; Hohenstein et al., 2014; Schneider et al., 2017). Moreover, literature is fragmented regarding the differently developed and conceptualized forms of each management idea (Armstrong, 2006; Certo and Certo, 2011; Potocan et al., 2012; Carter et al., 2017), which can appear in business practice as: "concepts, methodologies, methods, techniques, and tools (Potocan et al., 2012, p. 292).

As academics like Cooper et al. (1997), Rigby (2001), and Kannan and Tan (2005) suggested, we focused our study on research of MTs. Rigby (2001) specified MTs as "sets of specific management processes, exercises, and analytical frameworks"; other management authors use the term without a detailed definition (Porter, 1996; Maresova, 2010; Roriz et al., 2017). Following Rigby (2001) we define MTs as "entities of processes, exercises, and analytical frameworks aimed to support the implementation of management ideas on the operational level of enterprise".

The literature offers a lot of evidences about MTs utilization in organization (Wang et al., 2015; Harrison and Kelley, 1993; Jaeger and Adair, 2016; Powell, 1995). Dominant are studies of one tool (Maresova, 2010; Jaeger and Adair, 2016; Wilson, 2010; Psomas et al., 2014) or a smaller number of contently similar tools (Soare, 2012; Choudhary et al., 2013; Nedelko et al., 2015). Less developed, and mostly theoretical in their nature, are studies encompassing larger numbers of MTs in organizations (Van Assen et al., 2009). Additionally, the present studies revealed contradictory courses and characteristics of usage, satisfaction, and knowing of individual, or some, MTs in enterprises (Rigby and Bilodeau, 2009; Kumar, 2010; Kaufman, 2015; Nedelko et al., 2017).

Our present study specifies and empirically analyzes existence and magnitude of the 25 most commonly used MTs in Slovenian enterprises through research of: (a) key drivers, which define usage of MTs, (b) correlations between MTs and enterprises' operating in SCs, and (c) influences of the selected MTs on enterprises' operating in SCs. 
An adequate discussion of the above mentioned issues is not possible without a (requisitely) holistic understanding and researching of MTs and other appearance forms of management solutions (Kast and Rosenzweig, 1972; Rousseau et al., 2016).

\subsection{Holistic understanding and researching of business}

More holistic understanding of enterprises' MTs is possible with consideration of interdependences in business reality through systems thinking which enables more (requisitely) holistic understanding of the business practice and MT construct (François, 2004; Mulej, 2007; Schneider et al., 2017).

In that framework enterprises define MT with selection of "(systems of) viewpoints, purposes, goals, methods, methodologies, circumstances of use, and characteristics of its users" (Nedelko et al., 2017; p. 917; also Wiener, 1956; see also Von Bertalanffy, 1968; Francois, 2004; Rousseau et al., 2016). Additionally, enterprises need to apply and add their specifics in accordance with their selected viewpoints for consideration (Mulej, 2007; Potocan et al., 2012; Christopher and Holweg, 2017).

Most management authors focused their research on individual MT through one-sided understanding (Bhamu and Singh Sangwan, 2014; Arunagiri and Gnanavelbabu, 2014; Cao et al., 2018). A holistic consideration of multi-functional or even multi-disciplinary, and multilevel approaches are not adequate developed (Kannan and Tan, 2005; Choudhary et al., 2013; Lambert and Enz, 2017).

In business practice each enterprise applied specific series of MTs, which originated from different scientific disciplines and corresponding functional areas, but it uses different approaches for its consideration of these areas (Kaplan and Norton, 2008; Peet and Hartwick, 2009; Hugos, 2018). Traditional management studies focused their attention on one-aspect specialization, complicatedness, one-sided thinking and combination of methodological solutions inside single disciplines (Laeequddin et al., 2009; Chopra, 2018). The more recent systems disciplines - like Hard, Soft and Integrative systems theories (Wiener, 1956; Mulej, 2007; Von Bertalanffy, 1968) and the modern management discipline (Kast and Rosenzweig, 1972; Schneider et al., 2017; Valentinov, 2017) focused their research of MTs on bridges between different specialists, complexity, and systems/ systemic thinking through integrated approach for research of synergies between management and corresponding disciplines (François, 2004; Dubey et al., 2017; Fayezi et al., 2017).

Thus, some authors still see MTs as technical topics (Maresova, 2010; Arunagiri and Gnanavelbabu, 2014; Bhamu and Singh Sangwan, 2014); others are closer to the systems approach (Rousseau et al., 2016; Valentinov, 2017; Kasianiuk, 2018), while the SCs concept incorporated in the modern management is close to the integrative systems theories (Carter et al., 2017; Dubey et al., 2017; Lambert and Enz, 2017). According to the General system theory (Von Bertalanffy, 1968; François, 2004; Mulej, 2007) we exceed previous knowledge about MTs with analyzing and definition of the most frequently used MTs for further study of all important MTs in enterprises through Dialectical Systems Theory (Mulej, 2007).

Another undiscovered viewpoint is the multi-level consideration of MTs (Bowersox et al., 2012; Christopher, 2016; Chopra, 2018). As management ideas can 
appear in different forms following the specifics of each business level, their comparison is complicated and complex (Potocan et al., 2012; Carter et al., 2017). We followed academics, who suggest consideration of MTs and can realistically reflect the actual implementation of management solution on the operational level of enterprises (Cooper et al., 1997; Potocan et al., 2012; Schneider et al., 2017). Supply chain is also primarily applied on the macro level of enterprises, despite the fact that it can appear on any business level (Rothaermel, 2016; Lambert and Enz, 2017; Potocan and Nedelko, 2017). SC prevails as a leading management concept with importance for strategic business operating; this leads our decision for its consideration on the macro business level.

According to goals of our study, we defined enterprises' operating in SCs as their 'inclusion and participation in SCs' aimed at achievement of suitable results of their surviving and future development".

Consistent with selected study, we first considered the most frequently used MTs, and in the next step we study multilevel impacts of the selected MTs on enterprises' operating in SCs. We therefore proposed the following research question for our study:

RQ1: How do the commonly used management tools support supply chain operation of Slovenian enterprises?

\section{METHODOLOGY}

\subsection{Research instrument}

In this manuscript we used an instrument for assessing management tools utilization in organizations developed by Potocan and Nedelko (see Potocan et al., 2012) and which had been used for examination of management tools utilization in
Central Europe (Dabic et al., 2013; Potocan and Nedelko, 2017; Potocan et al., 2012). The questionnaire is comprised as follows (more about questionnaire see in Potocan et al., 2012). First part includes statements about usage, knowledge, satisfaction and desire to become familiar with 25 commonly used MTs listed. Second part includes general questions about MTs, like how long MTs is/are used in organization, which are most commonly used, etc. Third part includes typical statements to collect demographic data of respondents and their organizations.

\subsection{Sample and procedure}

The data collection was done in 2017 among employees in Slovenian organizations. 1000 questionnaires were sent to organizations in Slovenia via post, while 218

Table 1: Demographic characteristics of the sample

\begin{tabular}{lr}
\hline Variable name & Percentage \\
\hline Gender & \\
Male & $49.0 \%$ \\
Female & $51.0 \%$ \\
Education & \\
Bachelor's Degree & $50.5 \%$ \\
Master's Degree & $45.7 \%$ \\
PhD & $3.8 \%$ \\
Position & \\
Low Management & $40.9 \%$ \\
Middle Management & $35.2 \%$ \\
Top Management & $16.6 \%$ \\
Organization size & \\
Micro (<9) & $12.6 \%$ \\
Small (10 - 49) & $16.7 \%$ \\
Medium (50 - 249) & $49.5 \%$ \\
Large (>250) & $21.2 \%$ \\
Industry & \\
Manufacturing & $35.4 \%$ \\
Service & $64.6 \%$ \\
\hline
\end{tabular}


were returned, resulting in $21.8 \%$ response rate. Prior to the analysis we eliminated surveys with more than $5 \%$ of missing data. Thus, we used 198 answers in analysis. Respondents were on average 44.30 years old and they have 18.66 years of working experiences. Details about the sample are outlined in Table 1.

\subsection{Measures}

For measuring utilization of single MTs listed in the survey, respondents indicated their utilization of single MT with help of a Likert-type scale ranging from "I know and use the tool" (1) to "I don't know and don't use the tool" (3). Scales were also used to measure some of demographic information, like education level (from "primary school" to "Ph.D."), position of respondent in organization (from "specialists" to "CEO"), and organizational size (from "micro" to "large"). Respondents also provided the number of working years, as well as they indicate their gender. Finally, employees selected, whether their organization is involved in manufacturing, or in service industry.-

\subsection{Research design and analysis}

We developed a model of research (see Figure 1) in order to examine the impact of 24 MTs tools on enterprises operation in SCs. We also checked the impact of personal and organizational drivers of MTs (Dabic et al., 2013; Potocan et al., 2012).
Our analysis had two steps. In step 1, we present elements of descriptive statistics and correlations between the interesting variables. The expressed association between drivers of MTs utilization and SC as individual tools, associations between the commonly used MTs in enterprises, and enterprises' operation in SCs. Bivariate correlation analysis was used and Pearson's correlations coefficients are outlined. Due to the higher number of variables in our analysis - i.e. four personal, two organizational drivers of MTs usage, and 25 MTs, we are presenting correlations among variables of the interest in two tables. First, we provide linkages between drivers of MTs' utilization and utilization of SC tool. Second, we outline the linkages between 24 MTs utilization and utilization of $\mathrm{SC}$ at operational level.

In step 2, we used hierarchical regression analysis to determine the impact of the commonly used MTs on enterprises' operation in SCs, while also controlling the impact of MTs' drivers. Control variables, namely gender, education, working years, position in the organization, organizational size, and industry - were included first, followed by the 24 MTs.

We have the source of both, the independents variables - i.e. MTs and drivers, and dependent variable - i.e. enterprises' operation in SCs, in one instrument, which causes possibility of bias caused by using a

Figure 1: Field research model.

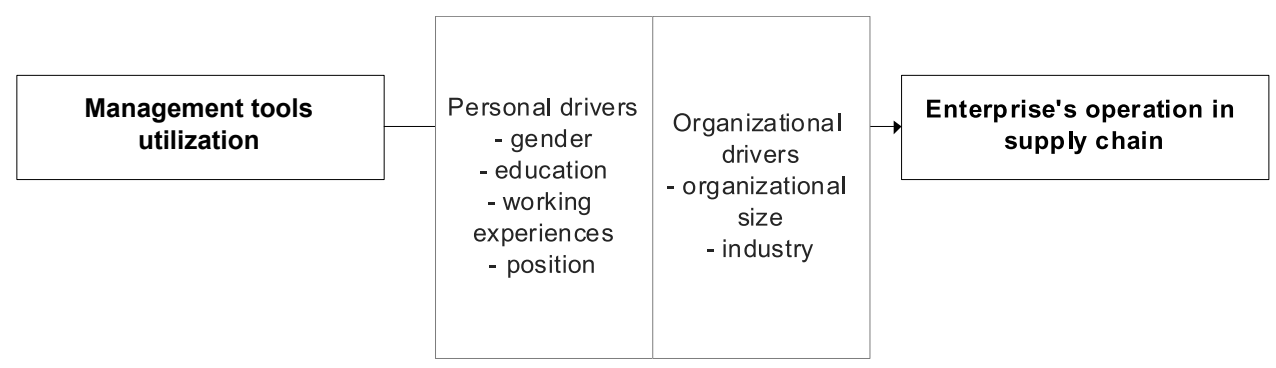


single method of data collection (Podsakoff et al., 2012). In frame of assessing common method variance, we loaded 6 drivers of MTs usage and 25 MTs onto a single factor (Podsakoff et al., 2003). Obtained latent factor explains $37.13 \%$ of the variance (50 $\%$ is acceptable). Multi-collinearity is not an issue in this research, since Although in Slovenia more than $95 \%$ of organizations have less than 10 employees, these organizations represent only $12.6 \%$ share in our sample. The rationale for focusing on larger organizations stems from the presumption that the MTs are more frequently utilized in larger organizations, for instance because of costly implementation, more users, etc. We presupposed that the considered MTs are used in enterprises of all sizes.

\section{RESULTS}

Firstly, we provide linkages between demographic variables, drivers of MTs utilization and enterprises operation in SC, as well as means and standard deviations for those variables (See Table 2).
Second, we outline the linkages between utilization of the 24 most commonly used MTs and enterprises operation in SC, as well as means and standard deviations for the considered variables (see Table 3).

Results in Table 3 indicate well, how the considered 24 MTs and enterprises, operating in SCs are interrelated, while providing no deeper insight into the actual impact of MTs on enterprises' operation in SCs. Utilization of the hierarchical regression analysis enables us to examine the impact of the commonly used MTs on enterprises' operation in SCs, and to check the impact of personal and organizational drivers of MTs usage. In the first phase of the hierarchical regression analysis, we entered personal and organizational drivers of MTs usage, followed by 24 MTs (Table 4).

The results reveal that personal and organizational drivers of MTs usage explain $23.2 \%$ of variance in enterprises' operation in SCs. Inclusion of 24 MTs in the analysis increase explained variance up to 53.9 $\%$. ANOVA results reveal that entry of

Table 2: Means, standard deviations and correlations between demographic variables, drivers of MTs utilization and enterprises operation in supply chainsa

\begin{tabular}{|c|c|c|c|c|c|c|c|c|}
\hline Variable & M & SD & 1 & 2 & 3 & 4 & 5 & 6 \\
\hline 1. Gender & 1.51 & 0.501 & 1 & & & & & \\
\hline 2. Education & 2.42 & 0.567 & -0.106 & 1 & & & & \\
\hline 3. Working years & 8.66 & 5.039 & -0.078 & $-0.266^{* *}$ & 1 & & & \\
\hline 4. Position & 2.32 & 1.250 & $-0.320 * *$ & $0.319^{* *}$ & $0.145^{*}$ & 1 & & \\
\hline 5. Organizational size & 2.79 & 0.919 & $-0.166^{*}$ & $0.260 * *$ & -0.069 & -0.028 & 1 & \\
\hline 6. Industry & 1.65 & 0.479 & $0.163^{*}$ & $-0.469 * *$ & $0.148^{*}$ & $-0.292 * *$ & -0.121 & 1 \\
\hline $\begin{array}{l}\text { 7. Enterprises' } \\
\text { operation in SCs }\end{array}$ & 2.16 & 0.706 & $0.189^{*}$ & $-0.472 * *$ & 0.078 & $-0.228^{*}$ & -0.098 & $0.315^{* *}$ \\
\hline
\end{tabular}

${ }^{a} N=184-198$ (due to the missing values)

$* p<.05$

$* * p<.001$ 
Table 3: Means, standard deviations and correlations between utilization of 24 most commonly used MTs and enterprises'operating in supply chains

\begin{tabular}{lccc}
\hline Management tool & Mean & SD & Correlation \\
\hline Loyalty management & 2.15 & 0.701 & $0.579^{* *}$ \\
Core competencies & 1.75 & 0.821 & $0.549^{* *}$ \\
Growth strategic tools & 2.29 & 0.709 & $0.506^{* *}$ \\
Scenario planning & 2.18 & 0.786 & $0.490^{* *}$ \\
Six sigma & 2.40 & 0.712 & $0.485^{* *}$ \\
Knowledge management & 1.72 & 0.744 & $0.484^{* *}$ \\
Benchmarking & 1.57 & 0.671 & $0.477^{* *}$ \\
Corporate blogs & 2.18 & 0.809 & $0.458^{* *}$ \\
Radio frequency identification & 2.53 & 0.666 & $0.449^{* *}$ \\
Lean production & 2.39 & 0.618 & $0.440^{* *}$ \\
Balanced scorecard & 1.97 & 0.866 & $0.433^{* *}$ \\
Mission and vision statements & 1.94 & 0.795 & $0.423^{* *}$ \\
Total quality management & 1.68 & 0.688 & $0.418^{* *}$ \\
Mergers and acquisitions & 2.03 & 0.649 & $0.413^{* *}$ \\
Shared service centers & 2.48 & 0.620 & $0.399^{* *}$ \\
Outsourcing & 1.52 & 0.666 & $0.389^{* *}$ \\
Collaborative innovation & 2.32 & 0.696 & $0.384^{* *}$ \\
Business process reengineering & 1.90 & 0.771 & $0.382^{* *}$ \\
Strategic alliances & 2.17 & 0.696 & $0.380^{* *}$ \\
Customer segmentation & 2.07 & 0.717 & $0.375^{* *}$ \\
Strategic planning & 1.77 & 0.624 & $0.358^{* *}$ \\
Customer relationship management & 1.89 & 0.725 & $0.352^{* *}$ \\
Consumer ethnography & 2.47 & 0.666 & $0.327^{* *}$ \\
Off-shoring & 2.55 & 0.626 & $0.196^{*}$ \\
\hline
\end{tabular}

${ }^{a} N=184-198$ (due to the missing values)

$* p<.05$

$* * p<.001$

personal and organizational drivers yielded a significant influence - i.e., $\mathrm{F}(6,158)=$ 7.935, $\mathrm{p}<0.001$, and their significant association - i.e., $F(30,134)=5.229, p<0.001$ with enterprises operating in SCs.

To sum up, according to the postulated research question, among the considered MTs, the most significantly associated enterprises operations include the SCs loyalty management, core competencies, growth strategic tools, benchmarking and scenario planning $(p<0.1)$. The impact of the remaining tools is weak and insignificant, including the traditionally considered support tools for supply chain operations, like lean production and outsourcing (Simchi-Levi et al., 2009). 
Journal of Contemporary Management Issues

Table 4: Hierarchical regression analysis of MTs on enterprises' operation in supply chains

\begin{tabular}{|c|c|c|c|c|}
\hline Variables & R Square & $\beta$ & $\mathbf{T}$ & Sig. \\
\hline Block 1 - Personal and enterprise drivers & 0.232 & & & \\
\hline Gender & & .165 & 2.203 & .029 \\
\hline Education & & -.041 & -.371 & .711 \\
\hline Working years & & -.110 & -1.437 & .153 \\
\hline Position & & .002 & .027 & .979 \\
\hline Enterprise size & & -.025 & -.334 & .739 \\
\hline Industry & & .100 & 1.235 & .219 \\
\hline Block 2: Management tools & 0.539 & & & \\
\hline Strategic planning & & .017 & .206 & .837 \\
\hline Customer relationship management & & .027 & .282 & .779 \\
\hline Customer segmentation & & -.123 & -1.263 & .209 \\
\hline Benchmarking & & .166 & 1.785 & .076 \\
\hline Mission and vision statements & & -.017 & -.174 & .862 \\
\hline Core competencies & & .296 & 3.078 & .003 \\
\hline Outsourcing & & -.075 & -.965 & .336 \\
\hline Business process reengineering & & -.102 & -1.147 & .253 \\
\hline Scenario planning & & .164 & 1.670 & .097 \\
\hline Knowledge management & & -.006 & -.056 & .955 \\
\hline Strategic alliances & & -.019 & -.209 & .835 \\
\hline Balanced scorecard & & -.059 & -.568 & .571 \\
\hline Growth strategic tools & & .157 & 1.820 & .071 \\
\hline Total quality management & & -.151 & -1.520 & .131 \\
\hline Shared service centers & & -.009 & -.100 & .920 \\
\hline Lean production & & .079 & .908 & .366 \\
\hline Collaborative innovation & & .019 & .198 & .843 \\
\hline Loyalty management & & .344 & 3.853 & .000 \\
\hline Mergers and acquisitions & & .053 & .601 & .549 \\
\hline Six sigma & & .018 & .161 & .872 \\
\hline Off-shoring & & -.124 & -1.524 & .130 \\
\hline Consumer ethnography & & .102 & 1.118 & .265 \\
\hline Corporate blogs & & -.048 & -.425 & 671 \\
\hline Radio frequency identification & & .029 & .290 & .772 \\
\hline
\end{tabular}




\section{DISCUSSION}

The study highlights the impact of the commonly used MTs in enterprises on enterprises' operating in SCs.

The findings extend the previous researches, which revealed courses and strengths of correlations between individual management solutions and performance of enterprises' participation in SCs (Prince and Kay, 2003; Choudhary et al., 2013; Fayezi et al., 2017). For example, Kannan and Tan (2005) established the extent in which Just in time, and Total quality management are correlated with SCs, and how their synergetic utilization impacts enterprises' results. Focusing on total quality management, increased usage of totally quality management leads to the decrease in enterprise participation in SC. In the frame of tradeoff between the focus on internal optimization of an organization vs. optimization of the entire SC (Chopra, 2018), this indicates that the surveyed organizations use total quality management tools for internal purposes of quality assurance; despite that, the Slovenian organizations are much involved in SCs (Potocan and Nedelko, 2014; Potocan and Nedelko, 2017). This can imply that the quality management systems are not well-related between partners in SCs.

Turning to the other MTs, there are several presumptions, mainly theoretical, that enterprises' involvement in supply chain management is supported heavily with outsourcing, lean operations, and strategic alliances (Simchi-Levi et al., 2009; Myerson, 2012; Laeequddin et al., 2009). This study offers surprising results, since outsourcing is in Slovenia the top used MT, but its usage is only weakly associated with enterprises' participation in SC. Thus, outsourcing has been recognized as the method of cost reduction and assuring effectiveness of organizations (Mickaitis et al., 2009), instead of enhancing enterprises participation in SC. Additionally, lean operations and strategic alliances, are again among the least used MTs in Slovenia (Potocan and Nedelko, 2017), and are consequently not considered to be important vehicles for supporting enterprises' participation in SCs.

Research results provide empirical support for presumptions about the positive impact of technical (Raisinghani et al., 2005; Fernandes et al., 2017), human resource (Hohenstein et al., 2014; Klafke et al., 2016), and business (Kim et al., 2006; Kaufman, 2015; Lambert and Enz, 2017); they arise management solutions on improvement of enterprises' participation in SCs. Moreover, results in Table 3 show significant associations between the considered MTs, which arise from different functional areas and $\mathrm{SC}$ on the operational level of business. This finding can be used to broader elucidate the previous failures in establishing a direct link between more, or even majority, of contently different MTs, and SC on the operational level of business. The present study offers an alternative explanation for previous simplifications and one-sided understanding of individual or some similar MTs, connections between similar MTs, and their partial influences on enterprises' internal and external operating. Additionally, we offer new avenues for improvement of enterprises' selection and utilization of multi-disciplinary streams of management solutions for realization of specific business goals on several levels of business operating.

Application of the most commonly used MTs in enterprises, reflecting the objective component of the model, emerges as a significant predictor of their operating in SCs. These results corroborate the previous evidences (Powell, 1995; Stacey et al., 2000; 
Potocan and Nedelko, 2014; Fernandes et al., 2017) on the influence of internal and external pressures on inclusion, participation and operating of enterprises in SCs. The fact that the previous research has not considered the multilevel perspective of SCs implies its lack of a requisitely holistic analysis of SCs, i.e. a need for a more systemic analysis of mechanism of SCs. The results in Table 4 revealed several specific issues regarding context, measurement, and analytical approaches to consideration of MTS inside the enterprises' operating in SCs. Consistence with previous studies' (e.g. Kannan and Tan, 2005) results in Table 4 reveals significant correlations between some of individual MTs and enterprises' operating in SCs among Slovenian enterprises.

That was expected for at least two reasons. First, managers' perception about importance of individual MTs leads their selection and usage of homogenous MTs, and tends to form managers' opinion about contribution of individual MTs to SCs. Consequently, managers exposed that the most commonly used MTs - i.e., loyalty management, core competences, benchmarking, scenario and contingency planning, and growth tools - also have a decisive impact on SCs operation; see more about usage of MTs in Slovenian enterprises in Dabic et al. (2013), Nedelko et al. (2015), and Potocan and Nedelko (2017). Second, the prevailing participation of Slovenian enterprises as supplier/provides in global SCs influences their managers' opinion about logicality of utilization of individual MTs for SCs. This result denotes that the surveyed managers understand MTs, which are in the forefront of the focal members of global SCs - i.e., just in time, total quality management, lean production, etc. - as necessary pre-conditions for functional optimization, and less related with optimization of working in broader SCs.
The fact that our work has failed to find a significant relationship between these MTs and SCs (Lambert et al., 1997; Lambert and Enz, 2017), implies that the understanding and knowing of business strategies among all employees importantly determines utilization and possible results of MTs utilization in enterprises. Support to this view is highly connected with need for continuous education and training of managers and other employees in enterprises.

\subsection{Implications}

Contrary to prior researches, we confirmed the impact of differently theoretically oriented MTs on enterprises' operation in SCs. This has been the missing link in the research about correlations between diverse streams of possible management solutions and possible specific orientations of enterprises. In our study, more management tools were measured than in earlier studies regarding management tools supporting enterprises' participation in supply chain. What is more, the relations between management tools utilization and enterprises participation in supply chain were examined empirically, where the most commonly used tools were considered simultaneously. This had not been done in prior studies. Examining the relations between utilization of management tools and supply chain management helps us elucidate how utilization of management tools supports the enterprises participation in supply chain. These findings have several contextual and practical implications.

Contextual applications indicate that we need to extend previous studies about relying on a single MT in enterprises with consideration of more simultaneous impacts of most MTs applied in the surveyed enterprises. In this line, enterprises need to focus their attention on selection and utilization of specific streams of MTs, which can 
adequately support achievement of specific selected business goals under the considered contextual conditions.

The theoretical applications indicate the need for additional knowledge about multidisciplinary consideration of business and especially SCs issues aimed to develop a more, or even requisitely, holistic understanding of contextual conditions, business practice, $\mathrm{SC}$, and application of $\mathrm{SC}$ in business.

Another promising stream of future studies is a critical analysis of cause-andeffect relationships between the currently applied streams of MTs, which originate in the prevailing economic circumstances and the necessary requirements for supporting the SCs operating in enterprises.

From the perspective of SCs' management, the correlations between MTs and SC in operational business level and decisive impacts of "business MTs" on operating of enterprises in SC, suggest that organizations should be very sensitive in their selection and balance of MTs, which can differently support managers' decision-making.

From a practical point of view, the findings have important implications for a more holistic behavior of organizations aimed at bettering of SCs operating. Organizations with additional content in in-service training can improve and accelerate managers' knowing and usage of the modern MTs. Equally, the findings imply that organizations may use SC orientation as their decisive criterion for selection of MTs for operation on all business levels. Both actions will strengthen the managers' orientation about the SC operation and may help enterprises to avoid dilemmas about optimization of their participations in SCs.

Comparing the results of this study and findings about the most significant MTs, which support enterprises' participation in SCs, like outsourcing, lean operations, and strategic alliances (Simchi-Levi et al., 2009; Myerson, 2012; Laeequddin et al., 2009), Slovenian organizations should rethink their focus about the outsourcing utilization; its focus should be shifted from organizational optimization towards supply chain management, too. The lean operation should also be enhanced, which reflects the current low level of digitalization of Slovenian manufacturing organizations (Kolberg and Zühlke, 2015; Mrugalska and Wyrwicka, 2017; Potocan and Nedelko, 2017).

These findings have implications for society as well, particularly the presumptions that managers knowing about the possible management solutions - i.e., in our case MTs - have long-term effects on economic performance of enterprises, as well as on achieving the necessary economic goals of society. Management theory revealed that any society can support further development of enterprises through adequate formal and informal education. Assuring that individuals - as employees or management - have more knowledge about production management, will reflect in their improved working in enterprises, and supporting their attention and possibilities for a constant development of enterprises.

\subsection{Limitations and future research}

\subsubsection{Limitations}

This paper has the following limitations. First, we followed multilevel analysis of MTs' impact on enterprises' participation in SCs. We cannot preclude alternative directions of these relationships as proposed by Dubey et al. (2017), who examine influences of SCs on enterprises selection and utilization of management solutions. Second, study of MTs is focused on operational business level, while other levels of 
business - like functional levels and areas of business - are not considered (Chopra, 2018; Christopher and Holweg, 2017). Third, utilization of a self-assessment approach, where participants in the survey expressed their perception about usage of MTs and enterprise's operating in SCs may result in more favorable assessment than the actual one, in comparison to peer-ratings (Podsakoff et al., 2003; Lau et al., 2016). Nevertheless, different arguments exist in literature (Weaver et al., 1999; Carroll and Buchholtz, 2008; Elm and Radin, 2012). Fourth, origin and characteristic of data about organizations and managers (Lau et al., 2016; Podsakoff et al., 2012) may limit the generalizability of our findings. Fifth, application of our results in enterprises have different development, economic, and societal settings and one should critically rethink them (Tamosiuniene and Jasilioniene, 2007; Mickaitis et al., 2009; Nedelko et al., 2015). Sixth, the cross-section design of this study allows for a direct examination of the considered relationships. Although our findings essentially support our presumptions, we cannot preclude an alternative thrust of relationships.

\subsubsection{Future research}

Accordingly, this study offers a research agenda for the future, based on a multilevel perspective that aims to integrate diverse theoretical frameworks and to develop an understanding of micro foundations for enterprises' operating in SCs. This study

\section{References}

1. Armstrong, M. (2006). A Handbook of Management Techniques: A Comprehensive Guide to Achieving Managerial Excellence and Improved Decision Making, Kogan Page, London. focused on the operational business level, while other levels of business - like functional levels and areas of business - are not considered (Chopra, 2018; Christopher and Holweg, 2017; Potocan and Nedelko, 2017). Thus, studies focusing on association between MTs utilization and enterprises' participation in SCs on other functional levels would be beneficial. Our findings outline several unexpected associations i.e., in terms of direction, strength and significance, between MTs usage and enterprises' participation in SCs. Thus, there are some deviations since MTs, typically associated with supply chain management activities, like outsourcing, lean production, six sigma, off-shoring are not in the forefront in our research (Simchi-Levi et al., 2009). The present research, as well as some previous ones (Dabic et al., 2013; Nedelko et al., 2015), were conducted in Slovenia and Croatia; research is needed to determine, what are the associations between MTs usage and enterprise participation in SC, in different cultures, regions, countries, circumstances, etc. For instance, it would be beneficial to know, if the associations vary substantially across geographic regions. Another important way of future research, in the frame of examining utilization of MTs to support enterprise participation in $\mathrm{SC}$, is to examine utilization of tools in the frame of trade-off between focus on internal optimization of an organization vs. optimization of the entire SC (Chopra, 2018).

2. Arunagiri, P. and Gnanavelbabu, A. (2014). Identification of High Impact Lean Production Tools in Automobile Industries Using Weighted Average Method, Procedia Engineering, Vol. 97, pp. 2072-2080.

3. Bhamu, J. and Singh Sangwan, K. (2014). Lean Manufacturing: 
Literature Review and Research Issues, International Journal of Operations \& Production Management, Vol. 34 No. 7 , pp. 876-940.

4. Bhosale, V. A. and Kant, R. (2016). Metadata Analysis of Knowledge Management in Supply Chain: Investigating the Past and Predicting the Future, Business Process Management Journal, Vol. 22 No. 1, pp. 140-172.

5. Blanchard, D. (2006). Supply Chain Management Best Practices, Wiley, New York, NY.

6. Bowersox, D., Closs, D. and Cooper, B. (2012). Supply Chain Logistics Management, McGraw-Hill/Irwin, New York.

7. Cao, K., Bo, Q. and He, Y. (2018). Optimal Trade-in and Third-Party Collection Authorization Strategies under Trade-in Subsidy Policy, Kybernetes, Vol. 47 No. 5, pp. 854-872

8. Carter, C. R., Kosmol, T. and Kaufmann, L. (2017). Toward a Supply Chain Practice View, Journal of Supply Chain Management, Vol. 53 No. 1, pp. 114-122.

9. Certo, S. and Certo, T. (2011). Modern Management Concepts and Skills, Prentice Hall, New York.

10. Chopra, S. (2018). Supply Chain Management: Strategy, Planning, and Operation, Pearson Education, Essex.

11. Chopra, S. and Meindl, P. (2015). Supply Chain Management: Strategy, Planning, and Operation, Prentice Hall, New York.

12. Choudhary, A. K., Harding, J., Camarinha-Matos, L. M., Koh, S. C. L. and Tiwari, M. K. (2013). Knowledge Management and Supporting Tools for Collaborative Networks, International Journal of Production Research, Vol. 51 No. 7, pp. 1953-1957.
13. Christopher, M. (2000). The Agile Supply Chain: Competing in Volatile Markets, Industrial Marketing Management, Vol. 29 No. 1, pp. 37-44.

14. Christopher, M. (2016). Logistics \& Supply Chain Management, Pearson, Harlow, United Kingdom.

15. Christopher, M. and Holweg, M. (2017). Supply Chain 2.0 Revisited: A Framework for Managing VolatilityInduced Risk in the Supply Chain, International Journal of Physical Distribution \& Logistics Management, Vol. 47 No. 1, pp. 2-17.

16. Cooper, M., Lambert, D. and Pagh, J. (1997). Supply Chain Management, The International Journal of Logistics Management, Vol. 8 No. 1, pp. 1-14.

17. Dabic, M., Potocan, V., Nedelko, Z. and Morgan, T. R. (2013). Exploring the Use of 25 Leading Business Practices in Transitioning Market Supply Chains, International Journal of Physical Distribution \& Logistics Management, Vol. 43 No. 10, pp. 833-851.

18. Dubey, R., Gunasekaran, A., Childe, S. J., Papadopoulos, T. and Fosso, W. S. (2017). World Class Sustainable Supply Chain Management: Critical Review and Further Research Directions, The International Journal of Logistics Management, Vol. 28 No. 2, pp. 332-362.

19. Fayezi, S., Zutshi, A. and O'loughlin, A. (2017). Understanding and Development of Supply Chain Agility and Flexibility: A Structured Literature Review, International Journal of Management Reviews, Vol. 19 No. 4, pp. 379-407.

20. Fernandes, A. C., Sampaio, P., Sameiro, M. and Truong, H. Q. (2017). Supply Chain Management and Quality Management Integration: A Conceptual 
Model Proposal, International Journal of Quality \& Reliability Management, Vol. 34 No. 1, pp. 53-67.

21. Francois, C. (Ed.) (2004). International Encyclopedia of Systems and Cybernetics, K.G. Saur, Munchen.

22. Harrison, B. and Kelley, M. R. (1993). Outsourcing and the Search for Flexibility, Work Employment and Society, Vol. 7 No. 2, pp. 213-235.

23. Hohenstein, N.-O., Feisel, E. and Hartmann, E. (2014). Human Resource Management Issues in Supply Chain Management Research: A Systematic Literature Review from 1998 to 2014, International Journal of Physical Distribution \& Logistics Management, Vol. 44 No. 6, pp. 434-463.

24. Hugos, M. (2018). Essentials of Supply Chain Management, Wiley, New York.

25. Jaeger, M. and Adair, D. (2016). Perception of Tqm Benefits, Practices and Obstacles: The Case of Project Managers and Quality Management Representatives in Kuwait, TQM Journal, Vol. 28 No. 2, pp. 317-336.

26. Kannan, V. and Tan, K. (2005). Just in Time, Total Quality Management, and Supply Chain Management: Understanding Their Linkages and Impact on Business Performance, OMEGA: The International Journal of Management Science, Vol. 33 No. 2, pp. 153-162.

27. Kaplan, R. S. and Norton, D. P. (2008). Mastering the Management System, Harvard Business Review, Vol. 86 No. 1, pp. 62-77.

28. Kasianiuk, K. (2018). A SystemCybernetic Approach to the Study of Political Power. Introductory Remarks, Kybernetes, Vol. 47 No. 6, pp. 1262-1276.

29. Kast, F. E. and Rosenzweig, J. E. (1972). General Systems Theory:
Applications for Organization and Management, The Academy of Management Journal, Vol. 15 No. 4, pp. 447-465.

30. Kaufman, B. E. (2015). Market Competition, Hrm, and Firm Performance: The Conventional Paradigm Critiqued and Reformulated, Human Resource Management Review, Vol. 25 No. 1, pp. 107-125.

31. Kim, S. Y., Jung, T. S., Suh, E. H. and Hwang, H. S. (2006). Customer Segmentation and Strategy Development Based on Customer Lifetime Value: A Case Study, Expert Systems with Applications, Vol. 31 No. 1, pp. 101-107.

32. Klafke, R. V., Lievore, C., Picinin, C. T., Francisco, A. C. D. and Pilatti, L. A. (2016). Primary Knowledge Management Practices Applied in Brazil, Russia, India and China (Bric) Industries from 2001-2010, Journal of Knowledge Management, Vol. 20 No. 4, pp. 812-828.

33. Kolberg, D. and Zühlke, D. (2015). Lean Automation Enabled by Industry 4.0 Technologies, IFAC-PapersOnLine, Vol. 48 No. 3, pp. 1870-1875.

34. Kumar, V. (2010). Customer Relationship Management, John Wiley \& Sons, Ltd, New York, NY.

35. Laeequddin, M., Sardana, G. D., Sahay, B. S., Waheed, K. A. and Sahay, V. (2009). Supply Chain Partners' Trust Building Process through Risk Evaluation: The Perspectives of Uae Packaged Food Industry, Supply Chain Management-an International Journal, Vol. 14 No. 4, pp. 280-290.

36. Lambert, D., Cooper, M. and Pagh, J. (1998). Supply chain management: Implementation Issues and Research Opportunities, The International 
Journal of Logistics Management, Vol. 9 No. 2, pp. 1-19.

37. Lambert, D. M. and Enz, M. G. (2017). Issues in Supply Chain Management: Progress and Potential, Industrial Marketing Management, Vol. 62 No., pp. 1-16.

38. Maresova, P. (2010). Knowledge Management in Czech Enterprises, $E$ \& M Ekonomie a Management, Vol. 13 No. 1, pp. 131-144.

39. Mickaitis, A., Bartkus, E. V. and Zascizinskiene, G. (2009). Empirical Research of Outsourcing in Lithuanian Small Business Segment, Inzinerine Ekonomika-Engineering Economics, Vol. 5, pp. 91-100.

40. Mrugalska, B. and Wyrwicka, M. K. (2017). Towards Lean Production in Industry 4.0, Procedia Engineering, Vol. 182 Supplement C, pp. 466-473.

41. Mulej, M. (2007). Systems Theory, Systems research \& behavior science, Vol. 24 No. 3, pp. 347-357.

42. Mullins, L. J. (2016). Management \& Organisational Behaviour, Pearson, Harlow.

43. Myerson, P. (2012). Lean Supply Chain and Logistics Management, McGrawHill, New York, NY.

44. Naylor, B. J., Naim, M. M. and Berry, D. (1999). Leagility: Integrating the Lean and Agile Manufacturing Paradigms in the Total Supply Chain, International Journal of Production Economics, Vol. 62 No. 1-2, pp. 107-118.

45. Nedelko, Z., Potocan, V. and Dabić, M. (2015). Current and Future Use of Management Tools, E a M: Ekonomie a Management, Vol. 18 No. 1, pp. 28-45.

46. Nedelko, Z., Mulej, M. and Potocan, V. (2017). How to requisitely holistically consider internal gaps of business ethics, Kybernetes: The international journal of systems \& cybernetics, Vol. 46 no. 6, pp. 914-932.

47. Peet, R. and Hartwick, E. (2009). Theories of Development: Contentions, Arguments, Alternatives, Guilford Press, New York, NY.

48. Podsakoff, P. M., Mackenzie, S. B., Lee, J. Y. and Podsakoff, N. P. (2003). Common Method Biases in Behavioral Research: A Critical Review of the Literature and Recommended Remedies, Journal of Applied Psychology, Vol. 88 No. 5, pp. 879-903.

49. Podsakoff, P. M., Mackenzie, S. B. and Podsakoff, N. P. (2012). Sources of Method Bias in Social Science Research and Recommendations on How to Control It. Annual Review of Psychology., Vol. 63, pp. 539-569.

50. Porter, M. E. (1996). What Is Strategy?, Harvard Business Review, Vol. 74 No. 6, pp. 61-78.

51. Potocan, V. and Nedelko, Z. (2017). Supply Chain Management and Management Tools, Pearson Education, Harlow.

52. Potocan, V. and Nedelko, Z. (2014). Management innovativeness: A case of Slovenian small- and medium enterprises, Transformations in business \& economics, Vol. 13 No. 1, pp. 41-59.

53. Potocan, V., Nedelko, Z. and Mulej, M. (2012). Influence of Organizational Factors on Management Tools Usage in Slovenian Organizations, Inzinerine Ekonomika-Engineering Economics, Vol. 23 No. 3, pp. 291-300.

54. Potocan, V., Nedelko, Z., Peleckiene, V. and Peleckis, K. (2016). Values, environmental concern and economic concern as predictors of enterprise environmental responsiveness, Journal of business economics and management, Vol. 17 no. 5, pp. 685-700. 
55. Powell, T. C. (1995). Total Quality Management as Competitive Advantage - a Review and EmpiricalStudy, Strategic Management Journal, Vol. 16 No. 1, pp. 15-37.

56. Prince, J. and Kay, J. M. (2003). Combining Lean and Agile Characteristics: Creation of Virtual Groups by Enhanced Production Flow Analysis, International Journal of Production Economics, Vol. 85 No. 3, pp. 305-318.

57. Psomas, E., Vouzas, F. and Kafetzopoulos, D. (2014). Quality Management Benefits through the Soft and Hard Aspect of Tqm in Food Companies, TQM Journal, Vol. 26 No. 5, pp. 431-444.

58. Raisinghani, M. S., Ette, H., Pierce, R., Cannon, G. and Daripaly, P. (2005). Six Sigma: Concepts, Tools, and Applications, Industrial Management and Data Systems, Vol. 105 No. 4, pp. 491-505.

59. Rigby, D. (2001). Management Tools and Techniques: A Survey, California Management Review, Vol. 43 No. 2, pp. 139-160.

60. Rigby, D. K. and Bilodeau, B. 2009. Management Tools and Trends 2009 [Online]. Available: http://www.bain. com.

61. Rigby, D. K. and Bilodeau, B. 2015. Management Tools \& Trends 2015.

62. Roriz, C., Nunes, E. and Sousa, S. (2017). Application of Lean Production Principles and Tools for Quality Improvement of Production Processes in a Carton Company, Procedia Manufacturing, Vol. 11 No., pp. 1069-1076.

63. Rothaermel, F. (2016). Strategic Management: Concepts, MacGraw Hill Education, New York.
64. Rousseau, D., Billingham, J., Wilby, J. and Blachfellner, S. (2016). The Synergy between General Systems Theory and the General Systems Worldview, Systema, Vol. 4 No. 1, pp. 61-75.

65. Schneider, A., Wickert, C. and Marti, E. (2017). Reducing Complexity by Creating Complexity: A systems Theory Perspective on How Organizations Respond to Their Environments, Journal of Management Studies, Vol. 54 No. 2, pp. 182-208.

66. Simchi-Levi, D., Kaminsky, P. and Simichi-Levi, E. (2009). Designing and Managing the Supply Chain: Concepts, Strategis and Case Studies, McGraw Hill, Boston, MA.

67. Slack, N., Chambers, S., Johnson, R. and Betts, A. (2006). Operations and Process Management, Prentice Hall, Harlow.

68. Soare, P. (2012). Opportunities for Driving Continuous Improvement through Tqm, Lean and Six Sigma within Business Process Management, Proceedings of the 6th International Management Conference: Approaches in Organisational Management, pp. 193-202.

69. Stacey, D., Griffin, D. and P., S. (2000). Complexity and Management, Routledge, London.

70. Valentinov, V. (2017). Wiener and Luhmann on Feedback: From Complexity to Sustainability, Kybernetes, Vol. 46 No. 3, pp. 386-399.

71. Van Assen, M., Van Den Berg, G. and Pietersma, P. (2009). Key Management Models: The 60+Models Every Manager Needs to Know, Prentice Hall, Harlow.

72. Von Bertalanffy, L. (1968). General System Theory, George Braziller, New York. 
73. Wang, J., Chan, P., Nguyen, L. and Favia, M. (2015). Core Competencies: Redefining Competition in the Global Economy, International Journal of Business Research, Vol. 15 No. 1, pp. 7-14.

74. Whetten, D. A., Felin, T. and King, B. G. (2009). The Practice of Theory Borrowing in Organizational Studies: Current Issues and Future Directions, Journal of Management, Vol. 35 No. 3, pp. 537-563.
75. Wiener, N. (1956). The Human Use of Human Beings: Cybernetics and Society, Doubleday Anchor, New York.

76. Wilson, L. (2010). How to Implement Lean Manufacturing, Mc-Graw Hill, New York.

77. Zinnes, C., Eilat, Y. and Sachs, J. (2001). Benchmarking Competitiveness in Transition Economies, Economics of Transition, Vol. 9 No. 2, pp. 315-353. 


\section{Journal of Contemporary Management Issues}

\section{KAKO MENADŽERSKI ALATI HOLISTIČKI PODRŽAVAJU OPERACIJE PODUZEĆA U LANCIMA NABAVE?}

\section{Sažetak}

U ovom se radu istražuje kako korištenje menadžerskih alata podržava operacije poduzeća u lancima nabave. Daje se kritički pregled rezultata prethodne studije, zasnovane na anketi 198 zaposlenika slovenskih organizacija, koji su procjenjivali korištenje menadžerskih alata u svojim organizacijama. Korištenjem hijerarhijske regresije, autori testiraju povezanost između korištenje menadžerskih alata i operacija poduzeća u lancima vrijednostima, pro čemu se utjecaj kontrolira varijablama, koje uključuju najznačajnije osobne i organizacijske pokretače korištenja menadžerskih alata. Rezultati pokazuju da su upravljanje lojalnošću, ključne kompetencije te scenarijsko $i$ kontigencijsko planiranje najsnažnije povezane s aktivnošću organizacija u lancima vrijednosti. Tradicionalni alati upravljanja lancima nabave, poput outsourcinga, lean proizvodnje i potpunog upravljanja kvalitetom se ne smatraju značajnim pokretačima sudjelovanja poduzeća u lancima opskrbe. Rezultati ove studije sugeriraju da je potrebno ponovno promišljati korištenje menadžerskih alata, u uvjetima kada poduzeća pokušavaju unaprijediti svoje sudjelovanje u lancima opskrbe. U ovom se radu analizira veći broj menadžerskih alata, negoli u prethodnim studijama, koje su se bavile menadžerskim alatima, koji podržavaju sudjelovanje u lancima opskrbe te su empirijski analizirani odnosi između korištenja menadžerskih alata te sudjelovanja poduzeća u lancima opskrbe. Također je analizirano istovremeno korištenje najčešćih menadžerskih alata, što nije bio slučaj u prethodnim studijama.

Ključne riječi: menadžerski alati, organizacija, upravljanje lancima opskrbe, sistemski pristup, sudjelovanje poduzeća u lancima vrijednosti. 